\title{
The clinical and microbiological effects of non-surgical periodontal treatments in necrotizing periodontal disease: case report
}

\author{
Sangmin Kim, Jaemin Lee, Dae-Young Kang, Hyun-Seung Shin* \\ 'Department of Periodontology, College of Dentistry, Dankook University, Cheonan, Republic of Korea \\ ${ }^{2}$ Department of Periodontology, Dankook University Dental Hospital, Cheonan, Republic of Korea
}

Necrotizing periodontal disease caused by plaque bacteria is showed clinical findings including pseudo-membrane, interproximal necrosis of the affected area, pain on palpation and gingiva bleeding. Microbiological examination is showed that patients have fusospirochetal bacteria. Two patients who were provisionally diagnosed as necrotizing periodontal disease received nonsurgical periodontal treatments in conjunction with dressing using $3 \%$ hydrogen peroxide and local antibiotic delivery. Before and 3 - 5 days after initial treatment, the levels of periodontal bacteria in gingival crevicular fluid obtained using quantitative PCR were compared. After treatment, patients recovered normal gingiva. The number of periodontal diseases related bacterial species decreased from seven or eight to one. As a result, periodontium of patients with necrotizing periodontal disease was recovered to normal periodontium by nonsurgical periodontal treatments. (J Dent Rehabil Appl Sci 2021;37(4):294-300)

Key words: nonsurgical periodontal treatment; necrotizing periodontal disease; bacteria; antibiotic

\begin{abstract}
서론
괴사성 치주질환(necrotizing periodontal disease, $\mathrm{NPD})$ 은 급작스러운 발현, 치간유두의 급속한 파괴, 동 통 및 치은 출혈 등을 특징으로 가지고 있다. ${ }^{1}$ Horning 과 $\operatorname{Cohen}^{2}$ 은 NPD에서 나타나는 임상적 증상들을 치 간유두의 괴사, 치은 통증, 치은 출혈, 위막, 악취, 발열, 불쾌감, 림프절의 변화 8가지로 보고하였다. 이러한 다 양한 증상들 때문에 Vincent's disease, fusospirochetal gingivitis, trench mouth 등 여러가지 이름으로 불리다 가 1999년에 와서야 괴사성 궤양성 치은염(necrotizing ulcerative gingivitis)과 괴사성 궤양성 치주염(necrotizing ulcerative periodontitis)을 포함하는 NPD로 정의되고 분류되었다. 이후 궤양이 괴사의 이차증상으로 간주되면 서 괴사성 치은염(necrotizing gingivitis, NG)과 괴사성

*Correspondence to: Hyun-Seung Shin

Associate Professor, Department of Periodontology, College of Dentistry, Dankook University, 119 Dandae-ro, Dongnam-gu, Cheonan, 31116, Republic of Korea Tel: +82-41-550-0261, Fax: +82-303-3442-7364, E-mail: perioshin@dankook.ac.kr Received: November 29, 2021/Last Revision: December 13, 2021/Accepted:

December 14, 2021
\end{abstract}

치주염(necrotizing periodontitis, NP)으로 변경되었다. ${ }^{3}$

$\mathrm{NPD}$ 와 감별진단해야 하는 질환으로는 포진성 치은 구내염, 박리성 치은염, 다형 홍반, 심상 천포창, 방선균 증(Actinomycosis), 연쇄구균성 구내염, 매독 감염으로 구내에 발생하는 점막반점, 디프테리아가 있다. 이 중 방 선균증, 연쇄구균성 구내염, 매독 감염으로 구내에 발생 하는 점막반점, 디프테리아 같은 특정 세균에 의한 감 염과 감별진단하기 위해 미생물학적 검사가 시행된다. ${ }^{4}$ Rosebury ${ }^{5}$ 는 NPD에서 방추균과 나선균이 혼합하여 존 재하는 방추스피로헤타 세균총이 관찰됨을 언급하였고, NPD에서 Treponema 종, Selenomaonas 종, Fusobacterium 종, Intermedius 종이 공통적으로 관찰된다고 Loesche 등 ${ }^{6}$ 이 보고하였다.

$\mathrm{NPD}$ 의 치료의 주 목표는 조직 괴사를 통해 나타나는 구내 통증 및 불편감을 경감시키는 것이다. 이를 위해 비

Copyright@ 2021 The Korean Academy of Stomatognathic Function and Occlusion. (c) It is identical to Creative Commons Non-Commercial License. 
외과적 치주치료가 선호되며, 치석제거술, 치근활택술 등 의 기계적 방법과 과산화수소 드레싱, 클로르헥시딘 세 정, 전신적 항생제 투여, 국소전달 항생제 적용 등의 화학 적 방법이 이용된다. 위와 같은 치료를 통해 조직 괴사 및 통증이 사라지고 나면 부골이 잔존하거나 분화구 양 상이 있을 경우에 추가적인 외과적 시술이나 처치가 고려 된다. 일반적으로 $\mathrm{NPD}$ 에는 기계적 방법에 전신적 항생 제를 병행치료 하는 것이 효과적이나 Gomes 등 ${ }^{8}$ 의 연구 에 따르면 NPD같은 급성의 치주질환에서는 기계적 방 법을 동반한 국소전달항생제 사용도 효과적이라고 하였 다. 또한 이렇게 기계적 방법을 국소전달항생제와 병행 하여 치료하였을 때 기계적 방법만 시술했을 때와 구강 미생물 환경을 비교해보면 치주염과 연관된 그람음성세 균 제거에 유의성 있게 높은 효과를 보이는 것도 보고되 었다. ${ }^{9}$

따라서 본 증례에서는 국소전달 항생제를 포함한 비외 과적 치주치료를 받은 NPD 환자들의 임상 사진과 실시 간 연쇄중합반응법을 이용한 정량분석으로 계측된 구강 내 미생물수 변화를 통한 치료 효과를 보고하고자 한다.

\section{증례보고}

\section{첫번째 증례}

첫번째 증례의 환자(P1)는 만 42세 여환으로 오른쪽 입천장 잇몸이 개인치과에서 치료를 받아도 차도가 없다 는 주소로 본원에 내원하였다. 초진시 \#14, 15 구개측 및
\#14 협측 치은 괴사 및 위막이 있는 상태였고, 파노라마 방사선 사진상 주소 부위 치조골 소실은 없는 상태였다 (Fig. 1A). 또한 NPD에 영향을 줄 수 있는 특별한 전신질 환이나 치과적 병력은 없었다. 이에 따라 괴사성 치은염 (Necrotizing gingivitis, NG)으로 잠정진단하고 치료를 진행하였다.

치료 진행 전에 주소 부위 치은열구에서 페이퍼포인트 (Millimeter marked paper point ${ }^{\mathrm{TM}}$, DiaDent, Cheongju, Korea)를 이용하여 미생물 검사를 위한 치은열구액을 채 취하였다. 채취 후 전악 치은연상 치석제거술(supragingival scaling, 이하 치석제거술)을 시행하였고, 주소 부위 에는 3\% 과산화수소를 적신 면봉으로 세정하였다. 항생 제는 Minocycline 성분의 국소전달항생제(Periocline ${ }^{\circledR}$, Sunstar, Osaka, Japan)를 치은 열구 및 과산화수소 세정 으로 위막이 제거된 출혈부위에 도포하였다. 추가적인 복용약 및 구강 세정제(Hydrogen peroxide solution 3\%) 는 따로 처방하지 않고 잇솔질은 통증이 있는 부위는 피 해서 시행하도록 지도하였다.

두번째 치료는 초진 3일 후에 시행하였다. 치료 진행 전에 미생물 검체 채취를 시행하였고, 주소부위에만 추 가 치석제거술, $3 \%$ 과산화수소수를 적신 면봉을 이용한 세정 그리고 국소전달항생제 도포를 시행하였다. 세번째 치료부터는 일주일 간격으로 미생물 검사 없이 치석제거 술과 $3 \%$ 과산화수소수를 적신 면봉을 이용한 세정 그리 고 국소전달항생제 도포하였으며, 다섯번째 치료까지 진 행하였다. 주소 부위의 임상적 개선을 평가하기 위해 치 료 전후 임상사진을 촬영하여 치유 과정을 관찰하였다
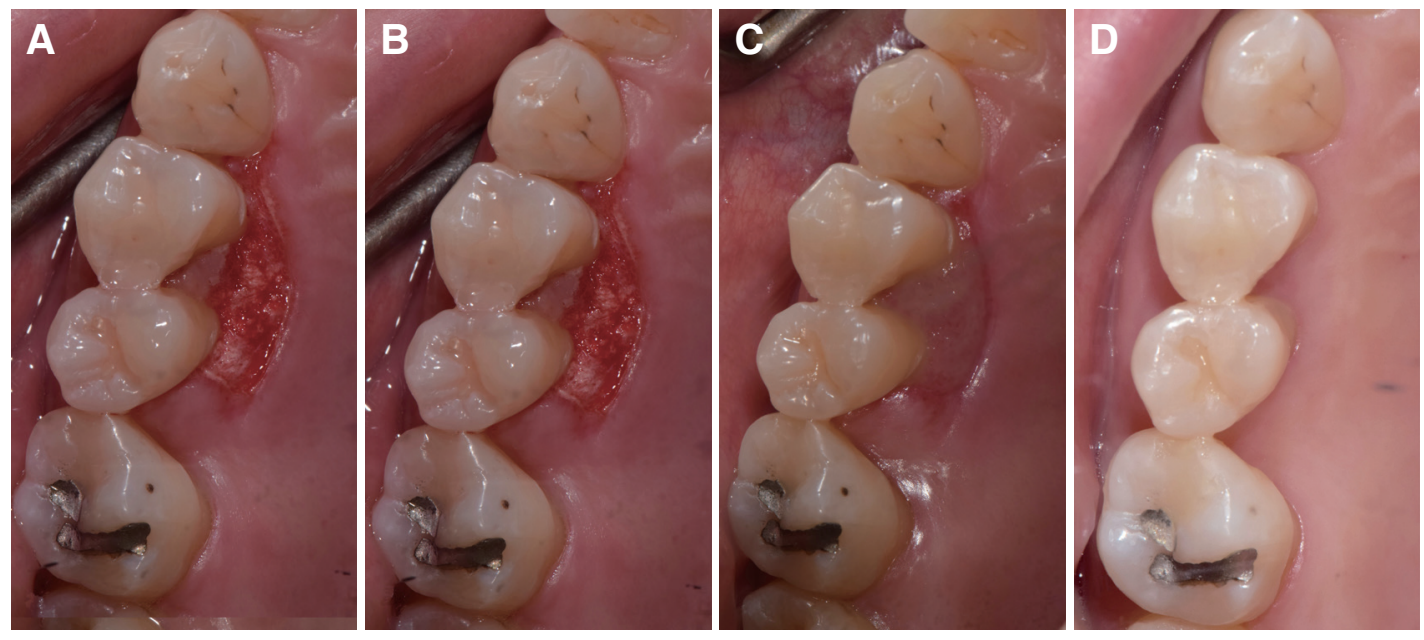

Fig. 1. Clinical photo of patient 1. (A) Before treatment of first visit: day 1, (B) After treatment of first: day 1, (C) Before treatment of second visit: day 3, (D) Recall check: after 10 weeks. 
(Fig. 1). 5 회의 시술 전후 위막이 제거되는 양상이 관찰 되었으며, 후속 치료가 진행됨에 따라 괴사부위 크기가 감소하였고, 5 회의 치료 후 정상치은 회복이 관찰되었다 (Fig. 1D).

초진과 두번째 치료 전에 채취된 치은열구액은 미생물 DNA 추출키트(ExgeneTM Clinic SV mini Kit, GeneAll, Seoul, Korea)를 이용하여 검체에서 구강미생물 DNA를 추출하고, 실시간 중합효소 연쇄반응법(ABI $7500 \mathrm{Fast}$ Real-Time PCR system, Life technologies, Daejeon, Korea)으로 DNA를 증폭함으로써 정량분석하여 미생 물수를 조사하였다. ${ }^{10} \mathrm{NPD}$ 와의 연관성을 확인하기 위 해 치주 질환과 관련이 있다고 알려진 Treponema denticola, Prevotella intermedia (Pi), Fusobacterium nucleatum (Fn), Aggregatibacter actinomycetemcomitans (Aa), Porphyromonas gingivalis, Tannerella forsythia, Parvimonas micra, Campylobacter rectus, Eubacterium nodatum, Prevotella nigrescens (Pn), Eikenella corrodens $(\mathrm{Ec})$ 의 11 가지 미생물 각각의 정량적 미생물수와 이를 포함한 총 구강 미생물의 수를 측정 하였다. ${ }^{11}$ 각 세균의 수는 표준균주의 genomic DNA를 10 배수로 희석하여 완성된 표준곡선에 대입하여 DNA $\mathrm{copy} / \mathrm{ml}$ 단위로 정량화하여 계측하였다(Table 1).

검사 결과를 살펴보면 P1의 초진 검사에서는 $\mathrm{Aa}, \mathrm{Pn}$, $\mathrm{Ec}$ 를 제외한 8종의 미생물이 검출되었으며, 총 구강 미 생물 대비 치주 질환 관련 미생물이 차지하는 비율이
$88 \%$ 였다. 재진 검사에서는 11 종의 미생물 중에서 $\mathrm{Fn}$ 만 검출되었으며, 총 구강 미생물 대비 치주 질환 관련 미생 물이 차지하는 비율도 $1.7 \%$ 로 확연하게 감소하였다.

\section{두번째 증례}

두번째 증례의 환자(P2)는 만 53세 여환으로 양쪽 어 금니 잇몸이 벗겨지고 치료받아도 좋아졌다가 재발하 여 계속 아프다는 주소로 내원하였다. 초진시 양측 구치 부 협측 치은 괴사, 출혈 및 위막이 점막치은경계 하방까 지 있는 상태였고, 방사선 사진상 치조골 소실은 없는 상 태였다(Fig. 2A). 과거에도 동일한 증상이 있었다는 치과 적 병력을 고려하여 재발성 괴사성 구내염(Necrotizing stomatitis, NS)으로 잠정진단하고 치료를 진행하기로 하 였다.

치료계획은 P1과 동일하게 전악 치석제거술을 시행하 고, 위막이 있는 구치부에 $3 \%$ 과산화수소를 적신 면봉 을 이용한 세정을 하였다. P2에서는 양측 구치부 세정시 심한 통증을 호소하여 리도카인(Huons Lidocaine $\mathrm{HCl}$ and Epinephrine Inj. 1:100,000, Huons, Seongnam, Korea) 국소마취하에 치석제거술과 과산화수소 세정을 진행하였다. 기계적 및 화학적 처치후에 치은열구 및 위 막이 제거된 치은 출혈 부위에 국소전달항생제를 도포 하고, 복용약은 처방하지 않고 잇솔질은 통증이 있는 부

Table 1. Realtime PCR quantitive data of oral bacteria at Patient 1 and patient 2

\begin{tabular}{crrrr}
\hline \multirow{2}{*}{ Oral bacteria } & \multicolumn{2}{c}{ Quantitative data (DNA copy/ml) } & \multicolumn{2}{c}{ Patient 2} \\
& Patient 1 & First visit & Second visit \\
\hline $\begin{array}{c}\text { Aggregatibacter } \\
\text { actinomycetemcomitans }\end{array}$ & Non-detected & Non-detected & Non-detected & Non-detected \\
Porphyromonas gingivalis & $5,636,377$ & Non-detected & Second visit & Non-detected \\
Tannerella forsythia & $190,985,326$ & Non-detected & $1,914,256$ & Non-detected \\
Treponema denticola & $7,909,079$ & Non-detected & $2,404,363$ & Non-detected \\
Prevotella intermedia & $79,250,133$ & Non-detected & Non-detected & Non-detected \\
Fusobacterium nucleatum & $70,631,755$ & 270,396 & $59,292,532$ & 847,227 \\
Parvimonas micra & $636,795,521$ & Non-detected & $239,883,292$ & Non-detected \\
Campylobacter rectus & $74,816,950$ & Non-detected & $153,461,698$ & Non-detected \\
Eubacterium nodatum & $7,211,075$ & Non-detected & $12,387,966$ & Non-detected \\
Prevotella nigrescens & Non-detected & Non-detected & Non-detected & Non-detected \\
Eikenella corrodens & Non-detected & Non-detected & Non-detected & Non-detected \\
Total & $1,216,186,001$ & $15,595,525$ & $549,540,874$ & $62,086,903$ \\
\hline
\end{tabular}


위를 피해서 하도록 지도하였다. P1에서 시행했던 미생 물 검사도 동일하게 진행하였다. 두번째 치료는 초진 5 일뒤에 진행하였으며, 초진 치료에 큰 차도 없이 양측 구 치부 치은에 전반적으로 위막 및 치은 출혈이 나타났다 (Fig. 2C). 구내 통증에도 차도가 없어 재진 시에도 국소 마취하에 전악 치석제거술을 진행하고, 주소 부위에 $3 \%$ 과산화수소수를 적신 면봉을 이용한 세정을 시행하였다. P2의 경우 초기 치료에 증상의 개선이 보이지 않아 일주 일 간격으로 총 20 회의 치주치료가 진행되었다. 장기간
의 치료를 진행하고 초진 22주 뒤에 체크하였을때 양호 한 치은상태 회복하였다(Fig. 2D).

미생물 검사 결과를 살펴보면 P2의 초진검사에서는 $\mathrm{Aa}, \mathrm{Pn}, \mathrm{Ec}$ 및 $\mathrm{Pi}$ 도 검출되지 않아 7종의 치주 질환 관 련 미생물이 검출되었으며, 총 구강 미생물 대비 치주 질 환 관련 미생물이 차지하는 비율은 $87 \%$ 로 확인되었다 (Table 1). 재진 검사에서는 P1과 동일하게 Fn만 검출되 었으며, 총 구강 미생물 대비 치주 질환 관련 미생물이 차 지하는 비율도 $1.4 \%$ 로 감소하였다.
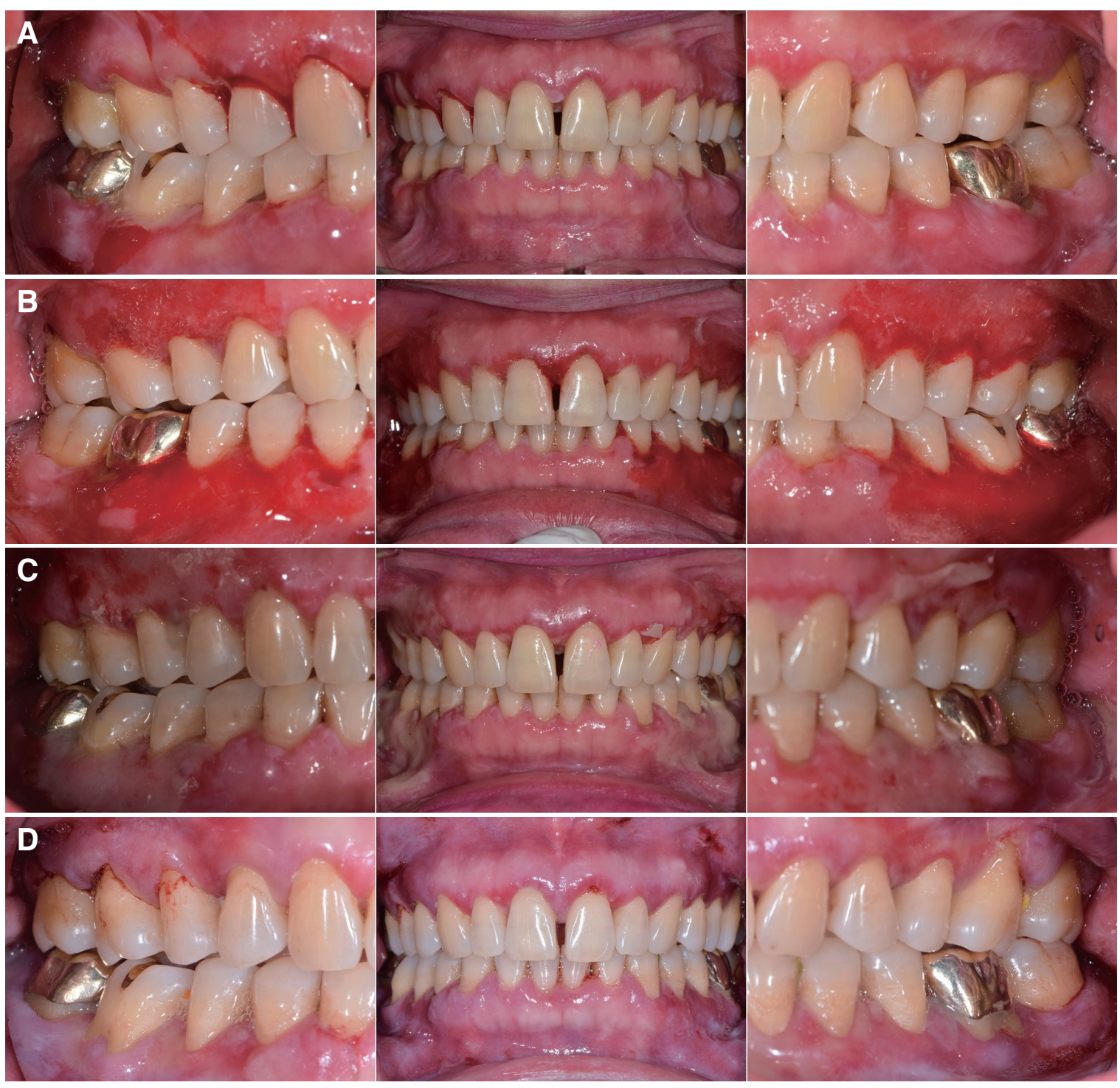

Fig. 2. Clinical photo of patient 2. (A) Before treatment of first visit: day 1, (B) After treatment of first: day 1 , (C) Before treatment of second visit: day 5, (D) Recall check: after 22 weeks. 


\section{고찰}

$\mathrm{NPD}$ 는 포진성 치은 구내염, 박리성 치은염, 다형 홍 반, 심상 천포창과 같은 질환들과 종종 혼동되어 정확한 감별진단이 필요하다. ${ }^{12}$ 특히 포진성 치은 구내염과 자주 혼동되는데 NPD와 다르게 아동에서 발생하고, $38^{\circ} \mathrm{C}$ 이 상의 고열과 치간사이에 한정되지 않은 구내증상으로 감 별진단이 가능하다. ${ }^{13}$ 본 연구에서 살펴본 2 명의 환자들 은 모두 만 40 세가 넘는 성인으로 $38^{\circ} \mathrm{C}$ 이상의 고열이 없고 위막이 관찰되어 포진성 치은 구내염은 제외하였다. 환자들의 구내에 나타난 치은괴사, 출혈 및 위막의 임상 증상들로 NPD를 잠정 진단하였다.

$\mathrm{NPD}$ 는 증상 범위에 따라 $\mathrm{NG}$, 괴사성 치주염 $(\mathrm{Nec}-$ rotizing periodontitis, NP) 그리고 NS로 분류되기도 한 다. ${ }^{14}$ 괴사부위가 치은조직에 국한되며 치조골 소실이 없 을 때 NG로 분류되며, P1이 해당하는 것으로 판단된다. $\mathrm{NP}$ 의 경우 부착 소실이 나타나고 괴사부위가 치주인대, 치조골을 포함한 치주조직에 한정되지만 NS는 점막치은 경계를 넘어가서 진행되는 경우를 의미한다. P2의 경우 양측 구치부 치은 MGJ 하방으로 위막과 출혈 양상을 보 여 NS로 판단된다.

또한 증례들의 치료기간을 살펴보면 P1의 경우 비교적 단기간에 치유가 되었지만, $\mathrm{P} 2$ 의 경우 155 일에 걸쳐 20 회의 치료가 진행되었다. Formicola 등 ${ }^{15}$ 은 NPD의 증세 에 따라서 score 0 에서 5 로 분류하였는데, 이 분류에 따 르면 국소적인 치간 치은 부위에서만 괴사가 나타난 P1 은 치간유두 끝부분에 국소적인 괴사소견을 보이고 탐침 이나 촉진시 출혈이 나타나는 Score 1으로 판단되며, 전 반적인 구치부 협측 치은 및 점막에 위막 및 괴사조직이 나타나고 장기간의 치료가 필요했던 P2 환자는 급성 증 세와 과거 병력이 있는 재발성 NPD인 Score 5 로 판단되 어 가장 긴 치료기간이 필요했던 것으로 사료된다. NPD 환자에서 치석제거술에 metronidazole 같은 전신적 항생 제 복용이 즉각적인 치료 효과를 보였다는 연구 ${ }^{5}$ 와 과산 화수소 구강 세정제를 같이 사용했을 때 더 효과적이라 는 연구를 고려해보면 본 증례에서 P2 환자의 치료기간 단축을 위해 추가적인 전신적 항생제 복용과 구강 세정 제 처방을 고려하지 못한 점에 한계가 있다고 생각된다.

미생물 검사결과를 살펴보면 초진 검사에서는 7 - 8종 의 치주 질환 관련 미생물들 총 구강 미생물 대비 $80 \%$ 이상을 차지하고 있었으나, 두번째 치료전에 시행한 미 생물 검사에서는 $\mathrm{Fn}$ 만 검출되는 모습이 관찰되었다. 이
는 치석제거술, 면봉을 이용한 3\% 과산화수소수 세정 그 리고 국소전달항생제 도포의 치료 효과로 대부분의 치 주 질환 관련 미생물이 실시간 연쇄중합반응법 검사에 서 검출되는 기준 이하로 감소되었지만, $\mathrm{Fn}$ 만 치료 전보 다 감소하였지만 검출되었다. 이는 아직 완치되지 않은 $\mathrm{NPD}$ 의 영향으로 판단되어 추가적인 치료를 진행하였 다. Loesche 등 ${ }^{6}$ 의 연구에서 $\mathrm{NPD}$ 환자들의 미생물 검사 에서 Fusobacterium 종이 우세한 경향을 보였던 것처럼 초 기 치료로 감소된 구내 미생물들 중에서 우세했던 Fn만 실시간 연쇄중합반응법 검사에서 검출된 것으로 보인다. 하지만 O'Connor 등 ${ }^{16}$ 의 실험실 연구에서 Minocycline 이 만성치주염 환자에서 채집된 미생물군들에 적용했 을 때 $A a, E c$, Bacteroides intermedius, Bacteroides gingivalis, Campylobacter sputorum, Streptococcus sanguis, Actinomyces viscosus, Wolinella recta, Haemophilus aphrophilus에는 유효한 억제효과를 보였지만 Fn과 Veillonella parvula에는 영향이 없던 것과 유사하게 $F n$ 을 제외한 다른 미생물만 변화를 보여 NPD 치료로 인한 미생물 세균총의 변화과정인지 Minocycline 성분의 국소전달항생제의 영향인지 확인이 필요할 것으로 판단된다. 또한 면봉에 사용된 $3 \%$ 과산화 수소도 구강내 치주 질환 미생물을 억제하는 영향 ${ }^{17}$ 도 있 었을 것으로 사료된다. 흔하게 발병하지 않는 NPD의 특 성상 대조군 설정을 통한 비교연구는 어렵지만 보고되는 증례들의 치료방법 비교를 통해서 재발성 NPD같은 난 치성 질환도 치료기간을 단축할 수 있는 더욱 효과적인 치료 방법의 개발이 필요할 것으로 생각된다.

\section{결론}

본 증례들에서는 NPD 환자들에게 국소전달항생제를 포함한 비외과적 치주치료 및 미생물 검사를 시행하였 다. 이러한 처치를 통해서 NPD로 발생하는 환자들의 구 내 통증 및 불편감을 감소시켰으며, 질병의 심도에 따라 회복 기간의 차이는 있었으나 임상적으로 양호한 치은을 회복하였다.

\section{ORCID}

Sangmin Kim https://orcid.org/0000-0001-9628-392X Jaemin Lee https://orcid.org/0000-0002-6366-0466

Dae-Young Kang https://orcid.org/0000-0002-4311-4118

Hyun-Seung Shin https://orcid.org/0000-0002-1410-9731 


\section{References}

1. Park JB. Symptoms \& treatment of ulcerative conditions. J Korean Dent Assoc 1983;21:449-52.

2. Horning GM, Cohen ME. Necrotizing ulcerative gingivitis, periodontitis and stomatitis: Clinical staging and predisposing factors. J Periodontol 1995;66: 990-8.

3. Herrera D, Retamal-Valdes B, Alonso B, Feres M. Acute periodontal lesions (periodontal abscesses and necrotizing periodontal diseases) and endoperiodontal lesions. J Clin Periodontol 2018;45:S78S94.

4. Newman MG, Takei H, Klokkevold PR, Carranza FA. Carranza's clinical periodontology. 12th ed. Amsterdam; Elsevier health sciences; 2011. p. 2719, 350-3.

5. Rosebury T. The etiology of Vincent's infection. In: Gordon SM, editor. Dental science and dental art. Philadelphia; Lea \& Febiger; 1938. p. 415.

6. Loesche WJ, Syed SA, Laughon BE, Stoll J. The bacteriology of acute necrotizing ulcerative gingivitis. J Periodontol 1982;53:223-30.

7. Lang NP, Berglundh T, Giannobile WV, Sanz M. Lindhe's clinical periodontology and implant dentistry. 6th ed. Hoboken; John Wiley \& Sons; 2021. p. 428-33.

8. Gomes EWB, Casarin M, Martins TM, da Silva AF. Local delivery therapies as adjuvants to non-surgical periodontal treatment of periodontitis grade C: a systematic review. Clin Oral Investig 2020;24:421324.

9. Nakagawa T, Yamada S, Oosuka Y, Saito A, Hosaka Y, Ishikawa T, Okuda K. Clinical and microbiological study of local minocycline delivery (Periocline) following scaling and root planing in recurrent periodontal pockets. Bull Tokyo Dent Coll 1991;32:6370.

10. Pfaffl MW. A new mathematical model for relative quantification in real-time RT-PCR. Nucleic Acids Res 2001;29:e45.

11. Haffajee AD, Socransky SS, Patel MR, Song X. Microbial complexes in supragingival plaque. Oral Microbiol Immunol 2008;23:196-205.

12. Malek R, Gharibi A, Khlil N, Kissa J. Necrotizing ulcerative gingivitis. Contemp Clin Dent 2017;8: 496-500.

13. Klotz H. Differentiation between necrotic ulcerative gingivitis and primary herpetic gingivostomatitis. N Y State Dent J 1973;39:283-94.

14. Novak MJ. Necrotizing ulcerative periodontitis. Ann Periodontol 1999;4:74-8.

15. Formicola AJ, Witte ET, Curran PM. A study of personality traits and acute necrotizing ulcerative gingivitis. J Periodontol 1970;41:36-8.

16. O'Connor BC, Newman HN, Wilson M. Susceptibility and resistance of plaque bacteria to minocycline. J Periodontol 1990;61:228-33.

17. Wennström J, Lindhe J. Effect of hydrogen peroxide on developing plaque and gingivitis in man. J Clin Periodontol 1979;6:115-30. 


\section{괴사성 치주질환 환자에서 비외과적 치주치료의 임상적 미생물학적 효과: 증례 보고}

\section{김상민 ${ }^{1}$ 대학원생, 이재민 대학원생, 강대영 ${ }^{2}$ 임상조교수, 신현승 ${ }^{*}$ 부교수}

${ }^{1}$ 단국대학교 치과대학 치주과학교실

${ }^{2}$ 단국대학교 치과대학 치과병원 치주과

치태세균에 의해 야기되는 괴사성 치주질환은 감염부위에서 위막과 치간사이의 연조직 괴사 및 출혈, 촉진시 통증과 치 은 출혈이 관찰된다. 환자들의 구내 세균을 조사해보면 방추균과 나선균이 혼합하여 존재하는 방추스피로헤타 세균총 을 가지고 있다. 본 증례는 괴사성 치주질환으로 잠정 진단된 환자 2 명을 대상으로 비외과적 치주치료, $3 \%$ 과산화수소 를 적신 면봉을 이용한 드레싱 후 국소전달항생제를 도포하였고, 치료 전과 초기 치료 3-5일 후 치은열구액을 채득하여 실시간 연쇄중합반응법을 이용한 정량분석으로 구강내 미생물수를 측정하였다. 비외과적 치주치료 후 감염부위 치은이 정상으로 회복되었고, 7종 이상 검출되던 치주질환 관련 미생물도 1종만 검출되었다. 결과적으로 비외과적 치주치료를 통해 괴사성 치주질환 환자들의 치주 조직을 정상으로 회복하였다.

(구강회복응용과학지 2021;37(4):294-300)

주요어: 비외과적 치주치료; 치주질환; 미생물; 항생제

*교신저자: 신현승

(31116) 충남 천안시 동남구 단대로 119 , 단국대학교 치과대학 치주과학교실

Tel: 041-550-0261 || Fax: 0303-3442-7364 | E-mail: perioshin@dankook.ac.kr

접수일: 2021년 11월 29일 | 수정일: 2021년 12월 13일 | 채택일: 2021년 12월 14일 